\title{
Professional nurses' attitudes towards providing termination of pregnancy services in a tertiary hospital in the North West province of South Africa
}

\author{
NE Mokgethi, MA Cur student \\ Department of Health Studies, University of South Africa
}

\author{
VJ Ehlers, Senior Lecturer \\ Department of Health Studies, University of South Africa
}

MM van der Merwe, Department of Health Studies, University of South Africa

\section{Keywords:}

Abortions, attitudes of nurses towards terminations of pregnancies, Choice on Termination of Pregnancy Act (no 92 of 1996), support for professional nurses, stigmatisation of terminations of pregnancy, termination of pregnancy services.

\section{Correspondence address:}

Dr VJ Ehlers

PO Box 65075

ERASMUSRAND

0165

Tel: (012) 429-6731

Fax: (012) 429-6688

E-mail: ehlervj@unisa.ac.za

\section{Abstract: Curationis 29(1): 32-39}

The Choice on Termination of Pregnancy Act (no 92 of 1996) was implemented during 1997. This study attempted to investigate professional nurses' attitudes towards rendering termination of pregnancy (TOP) services at a tertiary hospital in the North West Province of South Africa. A quantitative descriptive research design was used to study professional nurses' attitudes towards providing TOP services. The research results, obtained from questionnaires completed by professional nurses, indicated that most professional nurses' attitudes included that women should be at least 16 years of age to access these services; women should not be able to access repeated TOPs; nurses would prefer to administer pills rather than to use vacuum aspirations; nurses should work in TOP services by choice only. TOP centers should have better equipment, more resources and more staff members. Nurses working in TOP services would appreciate receiving more support from their families, friends, managers and communities.

Some professional nurses experienced guilt, depression, anxiety and religious conflicts as a result of providing TOP services. Despite the legalisation of TOPs, these services remained stigmatised. Professional nurses did not want to work in these services and also did not want to be associated with them.

\section{Opsomming}

Die Keuse vir die Terminasie van Swangerskap Wet (no 92 van 1996) is gedurende 1997 in werking gestel. Hierdie studie het gepoog om professionele verpleegkundiges se houdings jeens die dienste te bepaal in " $n$ tersiere hospital wat die dienste in die Noordwes Provinsie van Suid-Afrika verskaf. ' $n$ Kwantitatiewe beskrywende navorsingsontwerp is gebruik om professionele verpleegkundiges se houdings jeens die verskaffing van terminasie van swangerskapdienste te bestudeer. Die navorsingsresultate, wat verkry is uit vraelyste voltooi deur professionele verpleegkundiges, het aangedui dat die meeste professionele verpleegkundiges se houdings teenoor swangerskapterminasie ingesluit het dat vroue minstens 16 jaar oud moet wees wat die dienste benut; herhaalde swangerskapterminasies vir die selfde vrouens nie toegelaat moet word nie; pille eerder as vakuumaspirasies gebruik moet word; verpleegkundiges moet slegs uit vrye keuse in die dienste werk. 
Swangerskapterminasiedienste moet beter toerusting, meer hulpbronne en meer personeel kry. Verpleegkundiges wat in die dienste werk, sal meer ondersteuning vanaf hulle gesinne, vriende, bestuurders en gemeenskappe waardeer.

Sommige professionele verpleegkundiges het skuldgevoelens, depressie, angs en geloofskonflikte ervaar as gevolg van die aard van hulle werk. Ten spyte van die wettiging van terminasies van swangerskappe, het daar 'n stigma bly kleef aan die dienste. Verpleegkundiges wou nie in die dienste werk nie, en wou ook nie daarmee verbind word nie.

\section{Introduction and background information}

The issue of termination of pregnancy (TOP) has been a worldwide controversy. Many societies are divided into two groups "pro-choice" and "pro-life". "Prochoice" standpoints defend women's rights to choose whether or not to terminate a pregnancy. The "pro-life" movement claims that a foetus is a life, and therefore TOP is tantamount to taking a life (Everatt \& Budlender, 1999:102; Reiman, 1999:9).

It has been estimated that out of 44686 women admitted to hospitals every year with incomplete abortions, 12842 would become ill and 425 would die due to back street abortion related complications, especially sepsis (De Pinho \& Hoffman 1998:28). Nurses could help to reduce these morbidity and mortality statistics by providing safe, effective and accessible TOP services. However, nurses who harbour negative judgmental attitudes towards women requesting TOP services, are unlikely to provide such services. Thus it was essential to study nurses' attitudes towards TOPs in order to determine whether nurses' attitudes might facilitate or obstruct women's access to TOP services in the North West Province.

Nurses, being integral members of the communities they serve, also find themselves divided into these two "prolife" or "pro-choice" groups. They come from diverse cultural and religious backgrounds that influence their personal opinions, feelings, attitudes and perceptions when it comes to participating in TOP services. The study by Marais (1997:7) revealed that South African nurses' attitudes towards TOPs were not significantly influenced by their religious views. Walker's (1995:47) study also indicated that nurses working in primary health care facilities maintained that their participation in church activities did not affect their attitudes towards TOPs. However, Engelbrecht, Pelser, Ngwena and Van Rensburg (2000:6) reported that South African professional nurses experienced ethical and moral dilemmas when they had to refer patients to TOP services. Some of these professional nurses reportedly sabotaged referring pregnant women to TOP services. Nurses' views concerning the morality or immorality of TOP services could be determined by their philosophical perspectives on the moral status of the foetus (Jali, 2001:30).

Ethically, nurses as caregivers are taught to preserve life. In addition, the Democratic Nursing Organisation of South Africa (DENOSA) believes that nurses have a right to freedom of choice (Poggenpoel, Myburg \& Gmeiner, 1998:4). Therefore, the legalisation of TOPs by the Republic of South Africa's (RSA) government, might impose ethical and/ or moral dilemmas on nurses expected to provide TOP services. This study was done to determine nurses' attitudes towards providing TOP services in one referral hospital in the North West Hospital, offering TOP services to a large geographic area.

The World Health Organization (WHO) adheres to a strong frame of reference, which includes respect for an individual's choice regarding their personal health. The WHO (1998:1) further states that, approximately 20 million unsafe TOPs take place annually around the world resulting in 80,000 maternal deaths. Presumably some of these maternal deaths could be avoided if legalised TOP services were provided under hygienic conditions.

According to Rau (1996:2), prior to 1975, TOPs in the RSA were only justified in circumstances where the pregnancy constituted a threat to the life of the mother. Hence there was little resistance from the "pro-life" group. The implementation of the CTOP Act (no 92 of 1996) affords an opportunity to improve women's reproductive health by reducing the risk of death and disability associated with unsafe "backstreet" abortions (De Pinho \& Hoffman, 1998:28). Thus nurses who provide TOP services could be regarded as helping to save these women's lives, if they adhered to the "pro choice" approach. Alternatively "pro life" protagonists could regard nurses working in TOP services as enabling women to abort (or kill) their unwanted foetuses.

However, the CTOP Act (no 92 of 1996) was not accepted by some of the professional nurses. Evidence is given in the Barometer (1997:8) that with the promulgation of the CTOP Act (No 92 of 1996) the majority of nurses in the RSA refused to render TOP services or to work in hospital departments offering such services. According to Poggenpoel et al. (1998:5), professional nurses, who participated in their South African study, found it difficult to associate themselves with CTOPs, or to approve the provision of such services.

The RSA data available for legal TOPs, revealed that the Gauteng Province in the RSA, provided $48,3 \%$ of the total number of the TOPs in this country (Barometer, 1998:15). From February 1997 to January 1998, 64,5\% were first trimester TOPs and $35,5 \%$ second trimester TOPs. Everatt and Budlender (1999:101) revealed that $69,0 \%$ of the respondents criticised the CTOP Act (no 92 of 1996).

Professional nurses might have negative attitudes towards CTOPs, which could hamper the full implementation of CTOP Act (no 92 of 1996) in the RSA. This is reflected by the fact that, from July 2001 to July 2002 only two professional nurses were providing TOP services in the tertiary hospital, where this study was conducted, in the North West Province. Rabelo (2002:42) reported that nurses working in TOP clinics in the RSA were overworked and most of them did not want to work in these services. Despite the advent of safe legalised TOPs in South Africa, many women might fail to access these services, due to too few TOP sites and too few nurses providing these services (Albertyn, 2002:13). Pregnant women's rights to access legal TOP services, might produce conflicts with professional nurses' obligations to preserve life.

Unless nurses are willing and able to provide TOP services, the legalisation of TOP services in South Africa cannot produce the intended benefits to the 
pregnant women of this country. Consequently, it is necessary to determine professional nurses' attitudes towards providing TOP services. Based on this knowledge, programmes, can be designed to meet both the professional nurses' and the pregnant women's needs.

\section{The provision TOP services in South Africa}

In the RSA, a study conducted by Gmeiner, Van Wyk, Poggenpoel and Myburg (2001:75) showed that many nurses revealed negative attitudes and/ or experiences and suffered psychological discomfort due to the fact that they were directly involved with implementing TOP procedures.

Many communities might not accept TOPs, in many countries of the world. Marshall, Gould and Roberts (1994:568) reported that nurses in the USA lamented having to work in TOP services, and also did not approve of patients seeking these services. These attitudes among nurses continued to prevail despite the fact that TOPs were legalised in the USA during 1973 (Smith 2000:78). In the RSA, where TOP services were legalised during 1996 , some communities reportedly do not accept the nurses who provide TOP services. Gmeiner et al. (2001:75) reported that some nurses were victimised when it became known that they worked at clinics rendering TOP services. They were reportedly called "murderers" and "baby killers". Reportedly these nurses, as well as their families, were victimised to such an extent that these nurses had to send their children to distant boarding schools.

\section{Support required by professional nurses providing CTOP services}

The professional nurses who provide CTOP services need support from their colleagues, management and communities. Providing CTOP services could involve conflicts of interests between the profession, community, nurses' religious beliefs, and the employer's expectations. The study conducted by Varkey and Fonn (1999:6) revealed that those nurses who provided TOP services in the RSA, required support due to negative feedback form their colleagues. In the study conducted by Engelbrecht et al. (2000:11) some professional nurses revealed that they sometimes felt guilty about doing TOPs and recommended that TOPs should not be within the scope of practice of professional nurses in the RSA.

TOPs have social and psychological implications, which could have long-term consequences for the women, their partners and health care providers involved with the CTOP services in the RSA (Suffla, 1997:214). Many nurses in the RSA who provided TOP services were depressed and needed someone to talk to. Some nurses stated that they kept the nature of their jobs secret from their families and some also reported that church members only knew that they were nurses (Rabelo, 2002:42) but did not know which type of services they provided.

Unless sufficient resources are available, CTOP services might remain ineffective in the RSA, despite legal provisions. Reportedly there are neither enough nurses nor time to offer adequate counseling services before and after TOP procedures (Engelbrecht et al., 2000:11). Professional nurses in CTOP services were overworked and only a few of them really wanted to work in the CTOP facilities in the RSA (Rabelo, 2002:42).

\section{Research design}

A quantitative, descriptive study was used to determine nurses' attitudes towards providing TOP services. Descriptive statistics, based on calculations using the MS Excel (for Windows 2000) program, were used to summarise and describe the research results obtained from questionnaires completed by professional nurses.

\section{Population}

Polit and Hungler (1997:43) describe a population as the totality of all the subjects that conform to a set of specifications. The population for this study comprised all the professional nurses working in a tertiary public hospital in the North West Province of South Africa. The study population included all these professional nurses, whether they worked in TOP services or not. This decision was based on the fact that any professional nurse could be requested to render TOP services at any time. A total of 34 professional nurses worked at this hospital, but only 27 were willing to participate in this study. However, two of the 27 completed questionnaires contained answers only to section A (biographic aspects) of these questionnaires and had to be discarded. Thus the total number of participants in this study was 25 . As all the available members of the population could participate in the study, no sample was selected for this study.

\section{Research instrument}

A questionnaire, based on the literature review, regarding professional nurses' attitudes towards providing TOP services, was designed. The questionnaire comprised the following sections:

- $\quad$ section A requested biographic information, such as age, religion, marital status, and the number of children each professional nurse had

- $\quad$ section B asked questions about the professional nurses' attitudes, feelings and perceptions concerning TOPs and TOP services

- $\quad$ section $\mathrm{C}$ tried to determine whether professional nurses (working in TOP services) received support from their colleagues, managers and communities

- $\quad$ section D probed professional nurses' knowledge about the CTOP Act

- $\quad$ section E attempted to identify whether TOPs remained stigmatised in this area

- $\quad$ section $\mathrm{F}$ asked questions about the availability of staff and resources to render TOP services

- $\quad$ section $\mathrm{G}$ consisted of openended questions pertaining to professional nurses' attitudes and perceptions concerning CTOPs

The questionnaires were completed by professional nurses who could read and write English, obviating the need to translate the questionnaires (Brink, 1996 154; Polit \& Hungler, 1997:335).

\section{Reliability and validity of the research instrument}

The questionnaires were administered to professional nurses in clinics and public hospitals that did not form part of the research institution during pre-testing of the questionnaire. Ten professional nurses, working at institutions other than 
the hospital where the research was conducted, were requested to review, validate and verify the interpretations of the items in the questionnaire. The questionnaires were discussed with two nurse researchers and a statistician. Their suggestions included that all complex questions should be rephrased so that every item asked one specific question only. The ten nurses, who pretested the research instrument, encountered no problems in completing the questionnaires. They commented that the open-ended questions were time consuming to complete. After consultation with the supervisors of the study, these open-ended questions were maintained as it was hoped to gather some data about nurses' attitudes towards TOPs in their own words.

\section{Data collection process}

One researcher delivered the questionnaires personally and requested every professional nurse to complete the questionnaires within two days. Appointments were made for collecting the completed questionnaires 48 hours after delivery. A total of 27 completed questionnaires were collected at the prearranged times.

\section{Ethical considerations}

The respondents were informed in writing and during oral communications about the nature, purpose and scope of the study. They knew that they could withdraw from participating in the study at any time, without incurring any negative consequences whatsoever.

No names were requested on the questionnaire. No completed questionnaire could be linked to any individual, ensuring anonymity and confidentiality of the information provided. The researchers and the statistician were the only people who had access to the completed questionnaires. They were kept locked up and destroyed after the acceptance of the research report portraying statistics and discussions but no names of any participants.

Permission to conduct the study was requested from and granted by the relevant health care authorities of the North West Province as well as by the Research and Ethics Committee of the Department of Health Studies, University of South Africa.

\section{Data analysis}

The data were coded and entered in the

\section{Figure 1 Professional nurses' opinions about who should not received TOP services $(n-25 ; 92 \%=23$ out of 25 respondents}

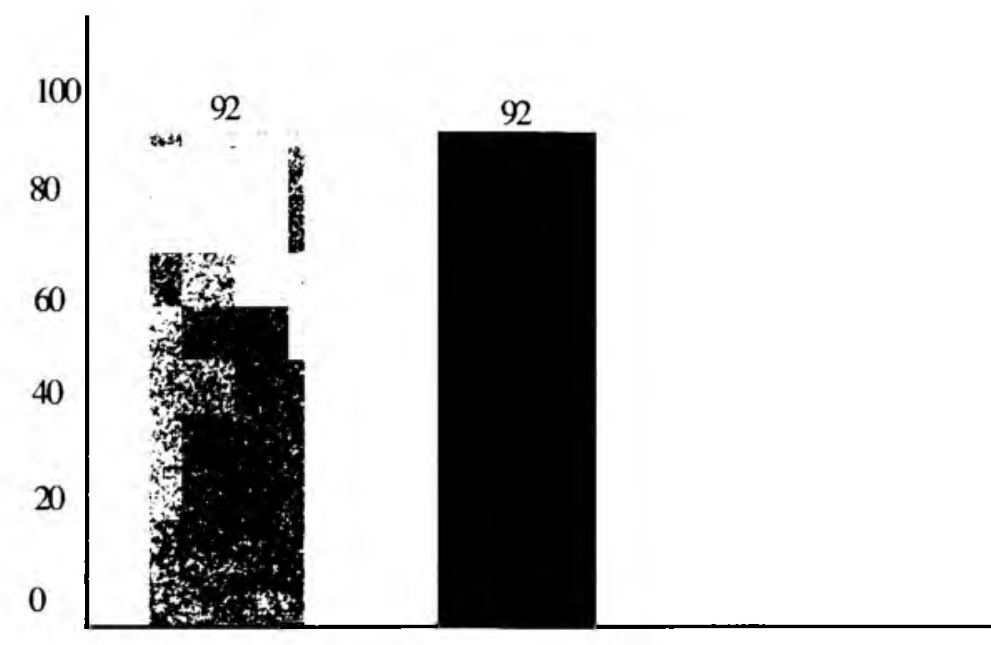

TOP before Never had any children

Microsoft Excel program by a statistician.

\section{Research results}

Twenty-seven respondents initially took part in the research. Two questionnaires had to be discarded, as these respondents did not complete any items other than those in Section A (biographical data). The research population comprised thirty-two professional nurses and the response rate was $78,1 \%(n=25)$.

\section{Biographic data}

Information was requested about participants' biographic data so that the other research results could be contextualised against the background knowledge of who actually responded to the questionnaires, providing the data for this investigation. The respondents' ages ranged from 23 to 45 years; with 5 (20\%) being older than 41 years of age; 9 (36\%) ranging from 37 to 40 years of age; and only $2(8 \%)$ being younger than 26 . Out of the 25 respondents $88,0 \% \quad(n=22)$ were Christians and no one belonged to the Muslim, Buddhist or Hindu faith in this sample; while three respondents did not indicate to which religions they belonged. Out of the 25 respondents, 12 were married, 11 had reportedly never been married, 1 was divorced and 1 was a widow. Only two (8\%) of the respondents had no children.

\section{Training received to provide TOP services}

Only $4(16 \%)$ of the 25 respondents received specific training to provide TOP services. Presumably the other $21(84 \%)$ professional nurses did not receive such training. As TOP services were implemented in this area during 2001 and the data were collected during 2003, it could be understood why only 3 respondents $(12 \%)$ reportedly had at least two years' experience of working in TOP services. The average number of TOPs handled by the respondents' departments was 22 per month, but this monthly figure ranged from 20 to 35 . In response to the question as to how many TOPs could be handled by each department every month, the responses ranged from 100 to 15 , but the majority $(76 \% ; n=19)$ considered 20 TOPs per month to be a manageable number. Future research should further investigate why only an average of 22 TOPs per month are performed at this facility. The possibility should be explored that some pregnant women might be unable to access these services.

\section{Professional nurses' attitudes towards providing top services}

Reportedly the professional nurses' attitudes towards providing TOP services were influenced by their perceptions as to which women should access these services.

\section{Professional nurses' attitudes pertaining to patients who should access TOP services}

The majority, namely $92,0 \%(n=23)$ of the professional nurses were of the opinion 
Figure 2 Support professional nurses received from various people (figures indicated on top of columns indicate the percentage of responses out of a total of 25)

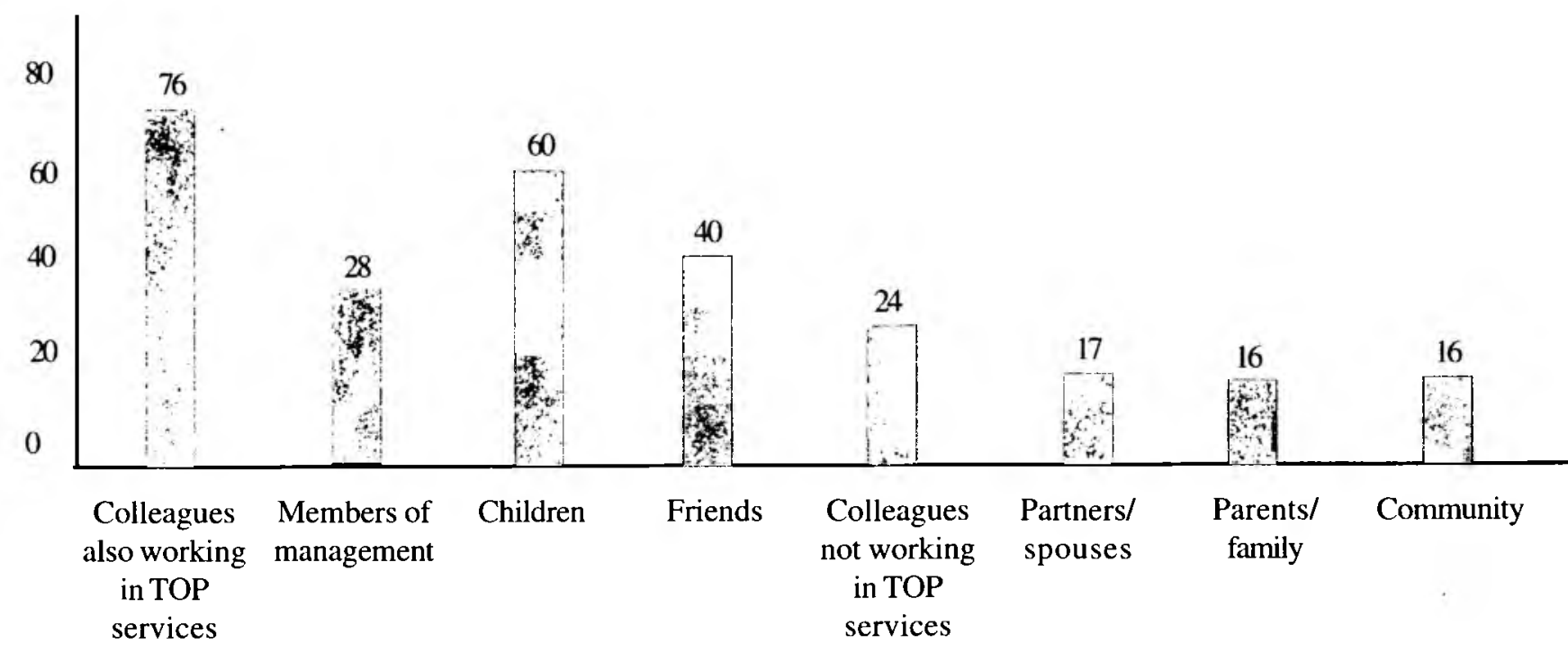

that women who had previous TOPs should not access TOP services for subsequent unwanted pregnancies. The majority of the respondents, namely $72 \%$, indicated that women who were expecting children with congenital abnormalities, should be allowed to receive TOP services.

Although the majority of the respondents, namely $76,0 \%(n=19)$ felt that women who were raped should be given TOP services, six $(24,0 \%)$ of the respondents felt that even after being raped women should not receive TOP services. However, according to the respondents, women who were victims of incest should, according to $84,0 \%$ $(\mathrm{n}=21)$, access TOP services.

Almost half of the sample, namely $48,0 \%$ $(n=12)$ respondents felt that the risk of suicide should be no reason for obtaining TOP services. Mental illness in the mother, on the other hand, was seen as an indication for TOP services by $72,0 \%$ $(\mathrm{n}=18)$ of the respondents, also women who suffered from mental retardation should be allowed to obtain TOP services $(72 \% ; \mathrm{n}=18)$. Many respondents, namely $68,0 \%(n=17)$ were of the opinion that women with HIV/AIDS should access TOP services, should they desire to do so.

Almost all respondents $(92,0 \% ; \mathrm{n}=23)$ felt that women who have no children should never be allowed to have a TOP. The respondents were divided in their opinions as to whether or not women with many children (grand multiparas) should be given TOP services, as only $56,0 \%$ $(n=14)$ of the respondents felt that TOP services should be offered to these women.

The respondents were also divided in their opinions as to whether or not poverty should be an indication to have TOP services; $52 \%(n=13)$ of the respondents felt that TOP services should be accessible to poor women.

Unplanned pregnancy was also seen by slightly more than half of the respondents as a reason for TOP services as $56,0 \%$ $(\mathrm{n}=14)$ felt that they should receive TOP services.

Most Professional nurses who participated in this study were of the opinion that TOP services should be rendered to women who requested TOPs, but should not be rendered to women who have never had any children. They also felt that any woman should only receive one TOP in her life time, with requests for subsequent TOPs being denied. Such denials would contradict the provisions of the CTOP Act (no 92 of 1996).

\section{Support received by professional nurses working in TOP services}

The data portrayed in figure 2 indicates that professional nurses received most support from colleagues working in TOP services, colleagues not working in these services and from their spouses/partners.
The Professional nurses did not perceive management to render much support to them. The need for such support was also emphasised by a study conducted by Poggenpoel et al. (1998:4) revealing that the majority of nurses did not want to work in TOP services, and that if they were forced to do so, they would leave the nursing profession rather than provide TOP services.

\section{Professional nurses' knowledge about and attitudes towards the CTOP Act}

In response to the question as to whether a copy of the CTOP Act was available in their hospital, the majority $(56,0 \% n=14)$ of the respondents indicated that the institution had such a copy, whereas $20,0 \%(n=5)$ did not know and 24,0\% $(n=6)$ indicated that their institution did not have a copy of the CTOP Act (No 92 of 1996).

Many of the respondents, namely $72,0 \%$ $(n=18)$ felt that they needed to read the Act often as they did not know it well enough. The majority, namely $80,0 \%$ $(n=20)$ of the respondents indicated that they read the Act less often than once every three months. Approximately half of the respondents $(56,0 \% ; n=14)$ indicated that the Act was acceptable and did not need to be revised. Those respondents who disagreed indicated that the Act should be amended to allow only women aged 16 or older to access TOP services.

While most respondents were 


\begin{tabular}{|c|c|c|c|c|c|c|c|c|}
\hline \multirow{2}{*}{$\begin{array}{l}\text { STATEMFNTSFROM } \\
\text { THEQUESTIONNAIRE }\end{array}$} & \multicolumn{4}{|c|}{ RESPONDENTS } & \multicolumn{4}{|c|}{ RESPONDENTS } \\
\hline & \multicolumn{2}{|c|}{$\mathrm{N}=35$} & \multicolumn{2}{|c|}{$\mathrm{N}=63$} & \multicolumn{2}{|c|}{$\mathrm{N}=\mathbf{4 7}$} & \multicolumn{2}{|c|}{$N=69$} \\
\hline \multirow[b]{3}{*}{ PNs required TOP services } & \multicolumn{2}{|c|}{ Agree } & \multicolumn{2}{|c|}{ Disagree } & \multicolumn{2}{|c|}{ Strongly agree } & \multicolumn{2}{|c|}{ Strongly disagree } \\
\hline & $\mathbf{F}$ & $\%$ & $\mathbf{F}$ & $\%$ & $\mathbf{F}$ & $\%$ & $\mathbf{F}$ & $\%$ \\
\hline & 8 & 32,0 & 5 & 20,0 & 9 & 36,0 & 2 & 8,0 \\
\hline $\begin{array}{l}\text { Penalised for requiring TOP } \\
\text { services }\end{array}$ & - & - & 9 & 36,0 & 2 & 8,0 & 13 & 52,0 \\
\hline TOP nurses caring people & 8 & 32,0 & 6 & 24,0 & 6 & 24,0 & 4 & 16,0 \\
\hline TOP nurses unfriendly & 1 & 4,0 & 8 & 32,0 & 1 & 4,0 & 14 & 56,0 \\
\hline Monitor patients hourly & 10 & 40,0 & 4 & 16,0 & 5 & 20,0 & 5 & 20,0 \\
\hline Leave patients & 1 & 4,0 & 10 & 40,0 & 4 & 16,0 & 9 & 36.0 \\
\hline $\begin{array}{l}\text { Do not want to be involved in } \\
\text { TOPs }\end{array}$ & 4 & 16,0 & 9 & 36,0 & 6 & 24,0 & 5 & 20,0 \\
\hline Patients to clear up their mess & - & - & 8 & 32,0 & 1 & 4,0 & 15 & 60,0 \\
\hline $\begin{array}{l}\text { Work in TOP services out of } \\
\text { choice }\end{array}$ & 3 & 12,0 & 4 & 16,0 & 13 & 52.0 & 2 & 8,0 \\
\hline
\end{tabular}

knowledgeable about the CTOP Act (no 92 of 1996), not one referred to the legal implications of obstructing women's access to TOP services.

\section{Respondents' attitudes towards TOP clients' gestation ages}

To determine at what gestation age TOPS should be done, the respondents had to respond to a number of statements. Some respondents namely $44,0 \%(n=11)$ indicated that they believed that all patients who received TOP services were less than 16 weeks pregnant. Only 12,0\% $(n=3)$ of the respondents indicated that they believed that $50-80 \%$ of the patients were within their second trimester of pregnancy.

Only $20,0 \%(n=5)$ of the respondents felt that some patients were too advanced (beyond 20 weeks) in their pregnancies to receive TOP services, but they believed that this was no more than $5,0-10,0 \%$ of the TOP clients.

\section{Respondents' opinions about nurses who usually render TOP services}

Respondents were requested to indicate how strongly they agreed with each given statement. However, not all respondents answered all the questions.
The following findings are presented in table 1 .

Some of the professional nurses $(36,0 \%$; $\mathrm{n}=9$ ) agreed that generally nurses refused to render TOP services and only $8,0 \%$ $(n=2)$ strongly disagreed that nurses generally refused to render TOP services.

Two respondents $(8,0 \%)$ strongly agreed that nurses should be penalised for refusing to render TOP services and $36,0 \%(n=9)$ disagreed while $52,0 \%(n=13)$ strongly disagreed, regardless of offences and penalties stated in the CTOP Act (no 92 of 1996:8) should any person obstruct access to TOP services. Some professional nurses $(32,0 \% ; n=8)$ agreed that nurses who rendered TOP services were generally caring people. Of the professional nurses $56,0 \% \quad(n=14)$ strongly disagreed with the statement that nurses who rendered TOP services were unfriendly. Only $50,0 \%(n=10)$ of the respondents agreed that TOP patients were monitored hourly. This aspect might require serious reconsideration, as the monitoring of TOP clients might be inadequate, based on these responses.

Even although only $14,0 \% \quad(n=10)$ disagreed with the statement that nurses generally leave their TOP patients to care for themselves, this could indicate that some patients did not receive adequate nursing care while undergoing TOP procedures. This potential lack of nursing care provided to TOP patients, might be attributable to South African nurses' dislikes for working in TOP services as reported by a number of previous research reports (Engelbrecht et al., 2000:13; Gmeiner et al., 2001:73; Poggenpoel et al., 1998:5).

No respondents agreed with the statement that nurses generally left patients to clean up after the pregnancies had been terminated; while $60,0 \%(n=15)$ strongly disagreed.

More than half of the respondents, namely $52,0 \%(\mathrm{n}=13)$, strongly agreed with the statement that they should work in TOP services out of choice only. The majority of the respondents indicated that they strongly agreed $(36 \% ; n=9)$ with the statement that the attitudes of the community influenced their attitudes toward TOPs and $24 \%(\mathrm{n}=6)$ agreed, whereas $8 \%(n=2)$ strongly disagreed and $32 \%(\mathrm{n}=8)$ disagreed. The majority of the respondents strongly agreed $(36 \% ; n=9)$ that the attitude of their families influenced their attitudes toward TOPs and $32 \%(n=8)$ agreed with this statement, whereas $4 \%(\mathrm{n}=2)$ strongly disagreed and 
$24 \%(n=6)$ disagreed.

Some respondents $(24 \%$; $=6)$ strongly agreed that the attitudes of their friends/ colleagues influenced their attitudes toward TOPs, and 36\% ( $n=9)$ agreed. Twenty percent $(n=5)$ of the respondents strongly disagreed and $20 \%(\mathrm{n}=5)$ agreed with the statement pertaining to their friends/colleagues' attitudes.

The aspect that had the greatest influence on the attitudes of the respondents toward TOPs was religion as $56 \%(n=14)$ of the respondents indicated that they strongly agreed that religion influenced their attitudes toward TOPs and $16 \%(\mathrm{n}=4)$ agreed, whereas only $4 \%(\mathrm{n}=1)$ strongly disagreed and $24 \%(n=6)$ disagreed. This finding concurred with the standpoint of Downs (2005:49) that theological science has a very simple conception of man, namely that "... as soon as he has been conceived, a man is a man (with a soul)". Nurses who adhere to these religious perceptions would regard any TOP as destroying a soul - possibly accounting for the great religious influence on nurses' attitudes towards TOPs.

\section{Conclusions}

The study revealed that nurses would prefer to work in TOP services out of their own free will, and not feel coerced to work there, nor fear retaliation should they refuse to do so. The training of nurses about CTOP issues was apparently inadequate. TOP services were still stigmatised and something needs to be done by the Government and the Department of Health to de-stigmatise TOP services. The study also revealed a lack of support for nurses who rendered TOP services.

The CTOP Act (no 92 of 1996) affords women an opportunity to reduce risks of death and disability associated with back street abortions (De Pinho \& Hoffman, 1998:28). Unless women can access TOP services, and unless nurses are willing and able to provide these services, mortalities and morbidities attributable to back street abortions, will persist despite the legalisation of TOPs in this country.

\section{Limitations of the study}

Limitations that were identified during the course of the study included that:

- The generalisation of the research results is limited because the study was conducted only in one tertiary hospital in the North West Province.

- Generalisation of the research results is further impeded by the small sample size of 25 .

- $\quad$ Most of the questions focussed on nurses who provide TOP services. The questionnaire was long which might have contributed to incomplete answers to some questions - or failure to respond to some items.

\section{Recommendations}

Notwithstanding the potential limitations of this study, the following recommendations can be made, based on the research results:

- nurses should be given a choice to work in TOP services and they should be given incentives to work there, such as extra remuneration or extra time off

- $\quad$ efforts should be made to make TOP services acceptable to the community as most of the nurses felt they would be rejected by the community if it was know that they worked in TOP services

- management should provide more support to nurses who work in TOP services workshops, incorporating values clarification sessions and the re-training of Professional nurses who are interested in working in TOP services, might assist these Professional nurses to render more effective TOP services and to experience less guilt, depression and anxiety

- debriefing sessions for all nurses who work in TOP services should be provided at least twice a year to enhance these Professional nurses' coping capabilities

- $\quad$ Professional nurses' spouses or partners and the community members should also be debriefed to address the stigmatisation issue whenever possible "pills" should be used rather than vacuum aspirations to terminated pregnancies as these "pills" appeared to cause less trauma to both Professional nurses, and possibly also to the TOP clients

definite research should be conducted to determine why an average of 22 TOPs are performed at this TOP clinic some women might be denied access to these services.

\section{Concluding remarks}

Despite the legalisation of termination of pregnancy services in South Africa since 1996, many women might remain unable to access these services. Unless women can access safe legalised TOP services, they will continue to use back street abortionists' services and “... the dangers which exist for women forced to seek back street abortions are ones which our society cannot afford" (Maforah, Wood \& Jeweks, 1998:13).

Professional nurses should respect the rights of women seeking TOP services, even though the nurses' attitudes might not condone TOPs. "The philosophy of nursing is about caring. Therefore, nurses have to uphold this by respecting their clients' right to life, right to privacy, right to human dignity and the right to equality as entrenched in the Constitution of South Africa" (Troskie \& Raliphada-Mulaudzi, 1999:41).

South Africa's TOP services require more resources, better equipment and more nurses willing and able to provide TOP services. The Department of Health should endeavour to enhance the working conditions as well as the general well-being of nurses working in these services.

\section{List of references}

ALBERTYN, C 2002: Legal comment on do-it-yourself abortion. Women's Health Project Review. Autumn: 13.

BAROMETER 1997: Towards ensuring access to reproduction choice. Reproductive Rights Alliance. 1(2):1-32.

BAROMETER 1998: Towards ensuring access to reproduction choice. Reproductive Rights Alliance. 2(1):1-31.

BRINK, H 1996: Fundamentals of research methodology for health care professions. Kenwyn: Juta.

CTOP ACT - see South Africa (Republic) 
DE PINHO, H \& HOFFMAN, M 1998:

Women's health, termination of pregnancy: understanding the new act.

Women's Health Continuing Medical

Education Journal. 2(1):22-28.

DOWNS, JA 1995: Opposing abortion. Agenda. 27:48-54.

ENGELBRECHT, MC; PELSER, AJ; NGWENA, C \& VAN RENSBURG, HCJ 2000: The implementation of the choice on termination of pregnancy act. Curatonis. 23(2):4-13.

EVERATT, D \& BUDLENDER, D 1999: How many are for and how many against? Private and public opinion on abortion. Agenda. 40:101-105.

GMEINER, A; VAN WYK, S; POGGENPOEL, M \& MYBURG, C 2001: Methodological issues involved in conducting qualitative research support for nurses directly involved with those women who chose to terminate their pregnancy. Health SA Gesondheid. 6(4):71-78.

JALI, MN 2001: Abortion: a philosophical perspective. Curationis. 24(4):25-31.

MAFORAH, F; WOOD, K \& JEWEKS R 1988: Back street abortion: women's experiences. Siren News. 6(1):8-13.

MARAIS, T 1997: Abortion values clarification workshops for doctors and nurses. Health Svstem Trust. 21:6-7.

MARSHALL, S; GOULD, D \& ROBERTS, J 1994: Nurses' attitudes towards termination of pregnancy services. Journal of Advanced Nursing. 20:567-576.

POGGENPOEL, M: MYBURG, CPH \& GMEINER, AC 1998: One voice regarding the legalisation of abortion: nurses who experience discomfort. Curationis. 21(3):27.

POLIT, DF \& HUNGLER, BP 1997: Essentials of nursing research methods, appraisal and utilization. Philadelphia: JB Lippincott.

RABELO, E 2002: Counselling help for those in need. Nursing Update:42-43.

RAU, L 1996: The constitutionality of abortion limiting legislation in South
Africa.Pretoria: University of South Africa. (MA dissertation).

REIMAN, J 1999: Abortion and the ways we value life. Lanham, MD: Rowman \& Littlefield.

SMITH, JH 2000: Abortion and reference for life. Tydskrif vir Crhistelike Wetenskap. 36(1/2):77-104.

SOUTH AFRICA (REPUBLIC) 1996: Choice on Termination of Pregnancy Act (no 92 of 1996). Pretoria: Government Printer.

SUFFLA, S 1997: Experiences of induced abortion among a group of South African women. South African Journal of Psvchology. 27(4):214-222.

TROSKIE, $R$ \& RALIPHADAMULAUDZI, FM 1999: Reproductive health rights of women in rural communities. Health SA Gesondheid. $4(1): 41-47$

VARKEY,SJ \& FONN, S 1999: Women's health project. http://www.hst.org.za/ sahr/99/chap26.htm.

WORLD HEALTH ORGANIZATION 1998: Safe motherhood initiatives. http:/ /www.who.int/ archives/whday/en/pages 1998/-10.html. 